\title{
Microwave-Assisted Pyrolysis of Biomass Waste: A Mini Review
}

\author{
Saleem Ethaib ${ }^{1,2}{ }^{\oplus}$, Rozita Omar ${ }^{1, *}{ }^{\mathbb{D}}$, Siti Mazlina Mustapa Kamal ${ }^{3}$, \\ Dayang Radiah Awang Biak ${ }^{2}$ a and Salah L. Zubaidi ${ }^{4} \mathbb{D}$ \\ 1 Department of Chemical and Environmental Engineering, Faculty of Engineering, \\ University Putra Malaysia, Serdang 43400, Selangor, Malaysia; dr.saleem@utq.edu.iq \\ 2 Department of Petroleum and Gas engineering, College of Engineering, University of Thi-Qar, \\ Al Nassirya 64001, Iraq; dradiah@upm.edu.my \\ 3 Department of Process and Food Engineering, Faculty of Engineering, University Putra Malaysia, \\ Serdang 43400, Selangor, Malaysia; smazlina@upm.edu.my \\ 4 Department of Civil Engineering, University of Wasit, Wasit 52001, Iraq; salahlafta@uowasit.edu.iq \\ * Correspondence: rozitaom@upm.edu.my
}

Received: 23 August 2020; Accepted: 15 September 2020; Published: 19 September 2020

\begin{abstract}
The utilization of biomass waste as a raw material for renewable energy is a global concern. Pyrolysis is one of the thermal treatments for biomass wastes that results in the production of liquid, solid and gaseous products. Unfortunately, the complex structure of the biomass materials matrix needs elevated heating to convert these materials into useful products. Microwave heating is a promising alternative to conventional heating approaches. Recently, it has been widely used in pyrolysis due to easy operation and its high heating rate. This review tries to identify the microwave-assisted pyrolysis treatment process fundamentals and discusses various key operating parameters which have an effect on product yield. It was found that several operating parameters govern this process such as microwave power and the degree of temperature, microwave absorber addition and its concentration, initial moisture content, initial sweep gas flow rate/residence time. Moreover, this study highlighted the most attractive products of the microwave pyrolysis process. These products include synthesis gas, bio-char, and bio-oil. The benefits and challenges of microwave heating are discussed.
\end{abstract}

Keywords: microwave-assisted pyrolysis; biomass; operating parameters; bio-char; bio-oil

\section{Introduction}

Biomass waste is a biopolymer abundant in nature as dry plant matter and as a low-value by-product of different activities by various industrial sectors such as forestry and argo-industrial residues (e.g., straws, husks, wood, trunks, peel, and bark), municipal solid waste (e.g., kitchen waste, waste paper and cardboard, wood items, and garden residues) and the effluents of wastewater treatment plants (e.g., sludge) [1,2]. The accumulation of this poses problems, safety hazards and health issues, as well as impacting on sustainable development in terms of the recycling of waste materials and resource recovery [3-5]. Since biomass wastes are biodegradable, they represent a significant source of renewable organic matter [6]. These features of biomass waste have encouraged research throughout the world to utilize these materials in sustainable technology development to solve such problems, i.e., to reduce waste and to generate clean and renewable energy at the same time.

Several conversion processes such as physical, thermal, biochemical-microbial and chemical have been utilized to transform biomass into energy $[7,8]$. It is important to note that the treatment of wastes is essential due to the restrictions in disposal, which are mainly related to cost and space. 
Incineration is the thermal treatment typically used in thermal waste treatment. Nonetheless, it leads to several problems such as air pollution (e.g., dioxins and furans), high cost, and ash disposal, to name a few [9]. In view of cost and space problems, reduction of volume has been the target of waste treatment. Pyrolysis has been proposed to achieve volume reduction and generate valuable products (bio-fuel) instead of incineration which is not viable. Air emissions usually pose the key environmental issue for most combustion systems, and due to the high cost of strict pollution control or pollution mitigation or compensation measurements. They have been a major obstacle to the viability of biomass combustion in many low air quality regions. Comparatively, the biomass pyrolysis products provide options for pollution relief for greenhouse gas and practical options for the particulate emissions of biomass combustion such as producing heat and electricity. Biomass pyrolysis thermally transforms biomass feedstock into bio-oil, biochar, and syngas in the absence of air/oxygen [10]. In this process, the organic material is thermally degraded by cracking the chemical bonds in an inert environment [11]. Generally, the end product of pyrolysis process are energy recovery products which have a high energy efficiency and generate minimal atmospheric emissions, etc. These products include gaseous, solid and liquid products (i.e., syngas, bio-oil, and bio-char). For many years, the traditional pyrolysis of biomass has been implemented by an electrical furnace and continually purged with nitrogen [12]. Due to microwave heating advantages against traditional heating, the successful implementation of microwave heating for thermal biomass waste treatment [13-15] has encouraged extensive research into microwave-assisted pyrolysis of biomass waste in the last decade. Current studies in microwave technologies seem to be offering the best waste management solution, allowing a range of microwave systems to be designed, developed, and optimized to process various waste products. It has been widely employed for biomass chemical transformation into valuable products [16,17]. Microwave energy technologies may deliver: (i) a reduction in waste volume, (ii) selective heating, (iii) rapid heating, (iv) increased capability for treating waste in-situ, (v) chemical reactivity, (vi) rapid and flexible processes that can also be remotely controlled, (viii) ease of control, (viii) energy savings, (ix) overall cost effectiveness, (x) equipment portability, and (xi) compared to some more traditional systems, cleaner energy sources, etc. [18].

The earliest known pyrolysis plant, utilizing microwave energy to breakdown polymers in used tires, was developed in the UK in 1989 [19]. Since the 1990s, the patents for the microwave pyrolysis of wastes have become abundantly available in the United States. In the last few years, many attempts have been made regarding microwaves to turn them into a possible route for biomass pyrolysis process treatment and converting biomasses into liquids and solids [20-23]. Various types of solid waste and biomass feedstock were recently utilized in microwave pyrolysis processes such as oil palm shell [24], paper deinking residue [25], plastics [26], wood sawdust [27], oily sludge [28], sewage sludge [29], cellulose [30], gumwood [31], and rice straw [32]. There are several challenges to be overcome for the processing of various materials applying microwave energy. The problems related with microwave processing of waste materials include the inherent difficulties with microwaves itself and another one inherent with the processed materials [33]. These difficulties include some aspects such as the ability of a material to change microwave energy to heat depending on the dielectric properties. Dielectric heating is a volumetric procedure whereby the heat is generated inside the material via selective absorption of electromagnetic energy. However, not all materials (e.g., transparent material) are easily heated by microwave heating. For instance, the materials are of high moisture whereby microwave heating can be very energy efficient compared to dry materials. Moreover, adding absorbers to transparent materials could assist the rise in reaction temperature. Another aspect is the challenge of measuring temperature in the microwave environment and the non-uniform heating behavior of the microwave is responsible for thermal damage in processed materials. This necessitates the need of special instrument design because the uniformity of the microwave field can be enhanced by increasing the size of the cavity. Moreover, the microwave leakage may harm the human being, requiring health and safety precautions and careful processing procedures. Thus, this study aims to 
identify the microwave-pyrolysis treatment and discusses various key elements that govern the end product yield of this process.

\section{Pyrolysis Process}

Pyrolysis is a thermal process in an inert environment and can be utilized to reduce the volume of biomass waste and convert these wastes into energy based products such as syngas or synthesis, liquid (bio-oil), solid (bio-char) [34]. Syngas or synthesis gas is a gas mixture produced from pyrolysis or gasification which includes hydrogen, carbon monoxide and carbon dioxide. The production of syngas could be an initial step in generating synthetic natural gas and to create ammonia or methanol. It has $50 \%$ the energy density of natural gas. Therefore, it can be burnt and utilized as a fuel supplement to generate electricity or manufacture steam. Bio-oil products and so-called tar, which is produced from pyrolysis usually consist of aqueous and oil fractions. It is a viscous black fluid that can be used as disinfectants and antiseptics in pitch, varnishes, cement, preservatives and medicines [35]. Pyrolysis bio-oils are complex mixtures consist of hundreds of organic compounds from a wide variety of chemical groups [36]. The main contents are water and small amounts of water-soluble organics such as alcohols, ethers, aldehydes and carboxylic acids. The amount of the water fractions is high, encouraged by the dehydration reaction of organic compounds as well as physically bonded and free water in the sample [37]. Bio-char is a form of solid product produced from heating in a natural biomass process such as gasification and pyrolysis. Due to its molecular structure, bio-char is more stable than the original carbon form chemically and biologically, thus making it more difficult to break down [38]. Bio-char from the pyrolysis process has various applications including energy and fuel applications and environmental applications. Bio-char in its original form, or after conversion to activated carbon, can be utilized as adsorbent (for removal of different pollutants), and agricultural applications: it can be added to soil improve its fertility [39]. The obtained yields of the end products of biomass pyrolysis depend on the pyrolysis procedure and its conditions. Not only can the composition of the raw material affect the yield and characteristics of the pyrolysis products, but the conditions of pyrolysis can also alter the direction of reactions and, thus, they have a significant effect on the yield and properties of the products. Temperature, heating rate, and residence time of vapors present in the reactor should be considered. The pyrolysis procedure may be separated into three subclasses according to these variables: slow, fast, and flash pyrolysis (see Table 1) [40].

Table 1. Pyrolysis modes and their process conditions.

\begin{tabular}{|c|c|c|c|c|}
\hline Pyrolysis Mode & $\begin{array}{l}\text { Residence Time } \\
\text { (s) }\end{array}$ & $\begin{array}{l}\text { Heating Rate } \\
\left({ }^{\circ} \mathrm{C} / \mathrm{s}\right)\end{array}$ & Temperature $\left({ }^{\circ} \mathrm{C}\right)$ & $\begin{array}{c}\text { Vapor Resentence } \\
\text { Time (s) }\end{array}$ \\
\hline Slow & $\begin{array}{c}>300 \text { (can go up to } \\
\text { several hours) }\end{array}$ & $0.1-10$ & $400-900$ & $\leq 550$ \\
\hline Fast & $0.5-10$ & 10-200 & $450-850$ & $0.5-10$ \\
\hline Flash & $<1$ & $>1000$ & $600-1200$ & $<0.5$ \\
\hline
\end{tabular}

Conventional or slow pyrolysis has been used, especially for the production of charcoal, for thousands of years. This type of pyrolysis can be simply summarized as [41]: (i) biomass is heated at temperatures to up to $\sim 500^{\circ} \mathrm{C}$; (ii) the heating rate is much slower compared to that utilized in fast pyrolysis; (iii) the vapor residence time varies from 5 to $30 \mathrm{~min}$; and (iv) feedstock can be held at a constant temperature or heated slowly. Fast pyrolysis is a high-temperature process whereby, in the absence of air, the feedstock is quickly heated to produce a dark brown mobile liquid with a heating value of about half that of traditional fuel oil. The produced liquid fuel may be used in static heating or electricity generation as an alternative to fuel oil [42]. Fast pyrolysis is a better process that gives a high yield of liquid product. This type of pyrolysis has several important features such as (i) providing a shorter residence time and a higher heating rate to encourage a higher production of bio-oil of up 
to $80 \mathrm{wt} \%$ on dry feed; (ii) a controlled temperature of around $500{ }^{\circ} \mathrm{C}$; and (iii) rapid cooling of the pyrolysis vapors. The most standard reactor configuration applied for fast pyrolysis is the fluid bed and the circulating fluid bed since they are easy to operate and are readily scaled up. For commercial scale, several technologies for fast pyrolysis are applied, meanwhile integrated process development efforts are triggered to focus on using fast catalytic pyrolysis [43,44].

In general, pyrolysis has a wide temperature range $\left(400^{\circ} \mathrm{C}-1200^{\circ} \mathrm{C}\right)$, as most volatiles form at $250{ }^{\circ} \mathrm{C}-500^{\circ} \mathrm{C}$ during biomass pyrolysis [45]. Limited volatiles can be recovered from biomass in the forms of bio-oil and syngas at the lowest pyrolysis temperature $\left(400^{\circ} \mathrm{C}\right)$, resulting in a high yield of bio-char. Three end products: gas, oil and char can result from a pyrolysis reaction of biomass which can be summarized in followed Equation (1) [46]:

$$
\text { Biomass } \rightarrow \mathrm{H}_{2}+\mathrm{CO}+\mathrm{CO}_{2}+\text { hydrocarbon gas }+\operatorname{tar}+\text { charcoal }
$$

The primary product of the pyrolysis process can be assumed as tar following Equation (2) [47]:

$$
\text { Tar } \rightarrow \mathrm{CH}_{4}+\mathrm{H}_{2} \mathrm{O}+\mathrm{C}_{\mathrm{m}} \mathrm{H}_{\mathrm{n}}+\mathrm{H}_{2}
$$

The secondary reactions occur to reach the equilibrium. The principal reactions that occur during the pyrolysis can be summarized in Equations (3)-(8), as indicated below [48]:

Methanation reactions:

$$
\begin{aligned}
& \mathrm{CO}+3 \mathrm{H}_{2} \leftrightarrow \mathrm{CH}_{4}+\mathrm{H}_{2} \mathrm{O} \\
& \mathrm{CO}_{2}+4 \mathrm{H}_{2} \leftrightarrow \mathrm{CH}_{4}+2 \mathrm{H}_{2} \mathrm{O}
\end{aligned}
$$

Methanol formation reactions:

$$
\begin{gathered}
\mathrm{CO}+3 \mathrm{H}_{2} \leftrightarrow \mathrm{CH}_{4}+\mathrm{H}_{2} \mathrm{O} \\
\mathrm{CO}_{2}+4 \mathrm{H}_{2} \leftrightarrow \mathrm{CH}_{4}+2 \mathrm{H}_{2} \mathrm{O}
\end{gathered}
$$

Char formation reaction:

$$
0.17 \mathrm{C}_{6} \mathrm{H}_{10} \mathrm{O}_{5} \rightarrow \mathrm{C}+0.85 \mathrm{H}_{2} \mathrm{O}
$$

Water gas shift reaction:

$$
\mathrm{CO}+\mathrm{H}_{2} \mathrm{O} \leftrightarrow \mathrm{CO}_{2}+\mathrm{H}_{2}
$$

Char is assumed as a solid carbon represented by the element carbon (C). Further cracking reactions simultaneously precede at both gas and solid phases as explained by the following Equations (9) to (14) [46]:

$$
\begin{gathered}
\mathrm{C}+\mathrm{H}_{2} \mathrm{O} \rightarrow \mathrm{CO}+\mathrm{H}_{2} \\
\mathrm{C}+\mathrm{CO}_{2} \rightarrow 2 \mathrm{CO}_{2} \\
\mathrm{C}+2 \mathrm{H}_{2} \rightarrow \mathrm{CH}_{4} \\
\mathrm{CH}_{4}+\mathrm{CO}_{2} \rightarrow 2 \mathrm{CO}+2 \mathrm{H}_{2} \\
\mathrm{C}_{\mathrm{m}} \mathrm{H}_{\mathrm{n}}+2 \mathrm{nH}_{2} \mathrm{O} \rightarrow \mathrm{nCO}+[2 \mathrm{n}+(\mathrm{m} / 2)] \mathrm{H}_{2} \\
\mathrm{C}_{\mathrm{m}} \mathrm{H}_{\mathrm{n}}+\mathrm{nH}_{2} \mathrm{O} \rightarrow \mathrm{nCO}+[\mathrm{n}+(\mathrm{m} / 2)] \mathrm{H}_{2}
\end{gathered}
$$

At a low pyrolysis temperature, it is difficult for the thermal cracking and water shift reactions to occur [46]. $\mathrm{H}_{2}$ increases continuously as the temperature increases $\left(500-900{ }^{\circ} \mathrm{C}\right)$, the contents of $\mathrm{CO}$ and HCs also increase only at $700-900{ }^{\circ} \mathrm{C}$ and $500-700{ }^{\circ} \mathrm{C}$, respectively, whilst at $800-900{ }^{\circ} \mathrm{C}$, $\mathrm{HCs}$ decrease slightly. These changes in the gas components lead to greater a value of gas products. According to Thormann and de Oro [49], high yields of liquefied products can be efficiently attained under optimized conditions as applied under fast pyrolysis. 
Another aspect of biomass pyrolysis, to enhance the process selectivity for certain products, is the pretreatment process of biomass prior to pyrolysis which can be carried out. Generally, most biomass waste, especially forestry and argo-industrial residues, comprising lignocellulosic biomass, includes three main components, which are named: cellulose, hemicellulose, and lignin. The role of pretreatment is to facilitate biomass conversion by changing the internal structure of lignocellulosic biomass materials by the decrystallization of cellulose and the removal of lignin/hemicellulose $[4,13,14]$. For this reason, the pretreament of lignocellulosic biomass has been widely applied in the conversion process of biomass into useful components for different industries such as energy, chemical production, food, and pharmaceutical components as can be seen in Figure 1. A wide variety of physical, chemical, and biological pretreatment approaches have been developed and employed in combination to pretreat lignocellulosic biomass [2,4]. A comprehensive discussion about the pretreatment process and its effect on the pyrolysis of lignocellulosic biomass was reported by Zadeh and his team [1].

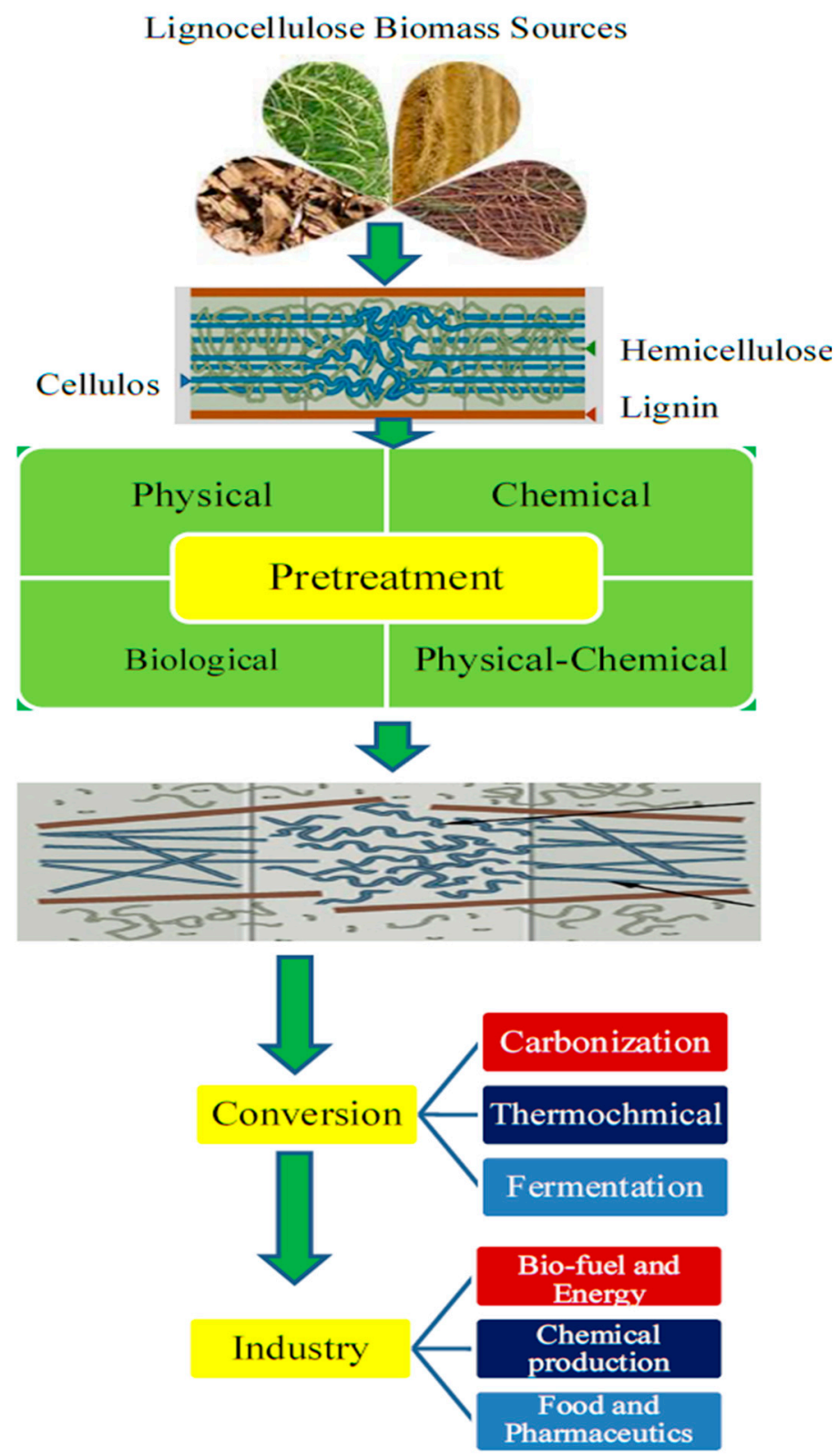

Figure 1. Graphic representation for the pretreatment process of lignocellulosic biomass and its role in biomass conversion into useful components. 


\section{Fundamentals, Benefits and Challenges of Microwave Heating}

Microwave technology is a type of electromagnetic radiation with wavelengths that vary from as short as one millimeter to as long as one meter. The microwave electromagnetic spectrum ranges between infrared and radio frequency, leading to a frequency range from $300 \mathrm{MHz}$ to $30 \mathrm{GHz}$. Microwave technologies are mainly used for telecommunications or energy transmission. The wavelength range between $0.1-25 \mathrm{~cm}$ is widely used in RADAR transmissions and the rest in telecommunications [50]. Most domestic and industrial microwave systems operate at either $2.45 \mathrm{GHz}(12.2 \mathrm{~cm})$ or $900 \mathrm{MHz}(33.3 \mathrm{~cm})$ to avoid interference with RADAR transmissions and telecommunications wavelength ranges [51].

Unlike conventional heating, microwave heating has several advantages, which make it an attractive proposition, for example, instantaneous starting and stopping and the generation of rapid heating within the material [52]. Many microwave-assisted organic reactions are accelerated as a result of this rapid heating compared to those attained using conventional methods. In shorter reaction times, higher yields and selectivity of the target compounds can be achieved. Moreover, there is no direct contact between the energy source and the reactants as microwaves travel through the vessel wall. Usually this vessel wall is almost transparent to microwaves, for direct interaction with reaction mixture components [53,54]. Moreover, non-thermal applications of utilize microwaves to determine the dielectric properties of many substances such as glass, paper, rubber, wood, and synthetic polymers [55]. Apart from the above-mentioned advantages, microwave non-thermal reactions are likely to happen, resulting in dramatically increase in the yield even in milder conditions. These microwave non-thermal effects are related to the system's response to electromagnetic energy and not related to the temperature variation [56]. Often, non-thermal effects are thought to accompany the microwave thermal effects. Microwave irradiation has been documented to cause a physical "explosion" effect among the microfibers, allowing the biomass to disintegrate the recalcitrant structures. In addition, it is known that the electromagnetic field used in microwaves induces physio-chemical effects which also accelerate the breakdown of the lignocellulosic biomass crystalline regions [57]. The magnetron device generates the microwave radiation which is located at the heart of most microwave systems. A microwave photon at a frequency of $2.45 \mathrm{GHz}(0.0016 \mathrm{eV})$ carries a small amount of energy which is not sufficient to cleave the chemical bonds and is also less than the energy of Brownian motion. As a consequence, microwave radiation by itself is unable to induce any significant reaction in materials [58]. However, Microwave heating poses some technical challenges [59]. Microwave energy can be converted into heat when a dielectric material having permanent or induced dipoles (polar molecules) is exposed to microwaves of a certain frequency. Consequently, microwave dielectric heating is based on the ability of a specific material to absorb the electromagnetic waves and generate heat by the oscillation of molecules. Microwaves consist of two oscillation fields; a magnetic field and an electric field, the latter being responsible for heating. The electric field causes heating in two ways: dipolar polarization and ionic conduction $[50,60]$. An example of a microwave setup schematic drawing for the pyrolysis process is depicted in Figure 2. This setup was successfully used by Mokhtar and his team [28] for the pyrolysis of biomass waste. 


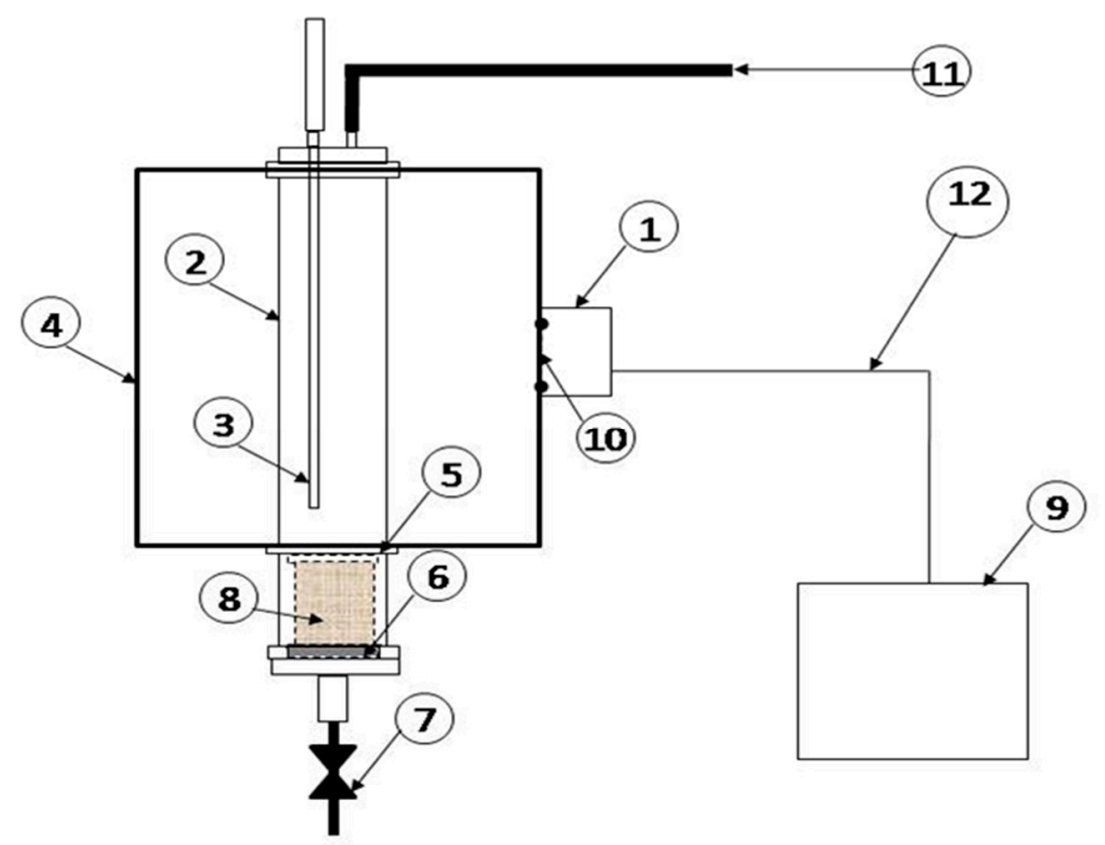

Figure 2. Schematic drawing of the modified microwave oven and the position of the quartz reactor: (1) magnetron; (2) quartz reactor; (3) thermocouple; (4) oven casing; (5) quartz distributor plate; (6) spring for quartz holder fitting; (7) $\mathrm{N}_{2}$ gas inlet; (8) quartz holder fitting; (9) cooler system for magnetron; (10) hole for wave into cavity; (11) gas outlet; (12) electrical connection [28].

By knowing the dielectric properties of a specific material, the capability of this material to convert microwave energy into heat can be understood. The operating temperature and the frequency of microwaves mainly influence the dielectric properties. Based on microwave absorption, there are generally three categories of materials concerning their interaction with microwave radiation. (i) Transparent material, i.e., a low dielectric loss material, which the microwave just passes through with very little attenuation (i.e., Quartze and Teflon). (ii) Opaque or conductors which reflect or do not allow penetration of microwaves such as metals. (iii) Absorbers which are high dielectric loss materials. When an absorber is placed in the microwave field, the material absorbs the microwave energy to a certain extent, depending on the dielectric loss factor. Water and graphite are two examples of good absorbers. There is a fourth type of interaction for materials with multiple phases where the different phases possess different loss values. These materials are good candidates for microwave heating and include semiconductors, oxides and wastes. Another feature of microwave processing is the material differential coupling which allows for selective heating. The addition of absorbers to transparent materials can help to raise the reaction temperature. Some reactions require a controlled environment, whereby transparent materials such as quartz and alumina ceramics can be used as reactors. However, having additives (absorber) may lead to undesirable impurities. Microwave processing is self-limiting at a temperature below the critical temperature of a material; thus, heating can stop after the procedure or stage is complete. This feature could also result in undesired decoupling during the heating of certain products, apart from the fact that it is difficult to maintain temperature [61]. The economics of microwave heating will ultimately become the decision-making point of using the technology. However, regardless of the advantages that would accrue if the solution were adopted, the final hurdle to the implementation of the industry can only be made with the achievement of a financial return on investment.

\section{Microwave-Assisted Pyrolysis}

Generally, different conditions of microwave-assisted pyrolysis will lead to varying yields of products. The efficacy of microwave pyrolysis ultimately relies on the operating conditions of this 
process. The factors that have the most impact on product recovery in microwave pyrolysis are temperature rate, microwave absorber addition, and its concentration (e.g., metal oxides and sulfides, carbon based materials and silicon carbide), initial moisture content, and initial sweep gas flow rate/residence time. It is essential to understand the effects and interactions between these parameters during the microwave assisted pyrolysis process. So, this section will highlight some of the facts and guidelines regarding the selection of operational conditions and the interactions between parameters. For instance, biomass pyrolysis at a low temperature, with a high heating rate and a short gas residence time, will favor the yield of liquid products. Meanwhile, low temperature and a low heating rate condition are required for maximum char production. However, high gas production will result from a high temperature, with a low heating rate and long gas residence time process.

\subsection{Effect of Feedstock Characteristics}

The microwave-assisted pyrolysis of various biomass feedstocks shows that biomass waste type (i.e., sludge wastes, agro-industry residues, forest biomass) and the feedstock characteristics (i.e., moisture $(w t \%)$, the components of proximate analysis $(w t \%)$, the elements of ultimate analysis $(w t \%)$, the fractions of lignocellulosic analysis, higher (or gross) heating value (HHV) and low (or net) heating value (LHV), and the particle size) directly influence the final products of pyrolysis process at different operating conditions [62]. For instance, the microwave-assisted pyrolysis of corn stover, bamboo leaves, rice husk, rice straw, sugarcane peel, sugarcane bagasse, and waste coffee grounds was achieved using similar treatment conditions [63]. This study showed there is no significant differences in the solid yields of the seven feedstocks. On the contrary, the liquid, and gas yields are highly influenced based on the type of feedstock. It was found that the corn stover had the lowest liquid yield, but it had the highest gas yield ( $40 \mathrm{wt} \%$ ). Meanwhile, rice husk had the highest yield of liquid (48 wt $\%$ ) but it had the lowest yield of gas $(30 \mathrm{wt} \%)$.

In the recent decades, waste sludge has been widely utilized in the global bioenergy or biogas production sector. The recent research has recorded that the microwave-assisted pyrolysis treatment offers certain advantages over other approaches in managing sewage sludge wastes [64]. Earlier, Menendez et al. [65] reported that wet sewage sludge could not be heated at temperatures higher than $200{ }^{\circ} \mathrm{C}$ unless mixed with a suitable microwave absorber. So, carbonaceous char residues from the previous experiments were used as an absorber. Dominguez et al. [66] conducted research to determine the feasibility of microwave and conventional pyrolysis for the production of synthesis gas (syngas) from sewage sludge. Two kinds of sludge were applied: aerobic and digested anaerobic sludge. When wet sewage sludge was pyrolyzed using microwave heating, the effect of the moisture content in producing higher quantities of $\mathrm{H}_{2}$ and $\mathrm{CO}$ was observed. Nevertheless, wet sewage sludge produced higher hydrocarbons from conventional pyrolysis resulting in a greater HHV for gases produced from conventional heating $\left(15-17 \mathrm{MJ} / \mathrm{m}^{3}\right)$ compared to the gas produced from microwave heating $\left(13 \mathrm{MJ} / \mathrm{m}^{3}\right)$.

The sewage sludge was pyrolyzed under microwave heating at temperatures up to $1000{ }^{\circ} \mathrm{C}$ using graphite as a microwave absorber $[67,68]$. A conventional electric furnace also was utilized to pyrolyze the sample to compare the outcomes gained from both approaches. The sample was homogenously blended with the graphite, and then heated for about $6 \mathrm{~min}$. The bio-oil products obtained from the microwave pyrolysis have a high calorific value $(33.9-36.8 \mathrm{MJ} / \mathrm{kg}$ ) and a low proportion of polycyclic aromatic hydrocarbons (PAHs) compounds. On the other hand, the bio-oil produced from traditional heating at high temperature enriched the PAH content. The use of microwave instead of using conventional heating was expected to be advantageous to pyrolyze large pieces of wood, thus perhaps eliminating the need to cut the sample [69]. During conventional heating, the materials are heated thoroughly as the heat is transmitted via conduction and/or convection from the surface into inside of heated matter. In contrast, microwave heating might induce hotspots within the material; therefore, the heating could be generated within the heated matter without the need for a transmission distance [70] as illustrated in Figure 3. 


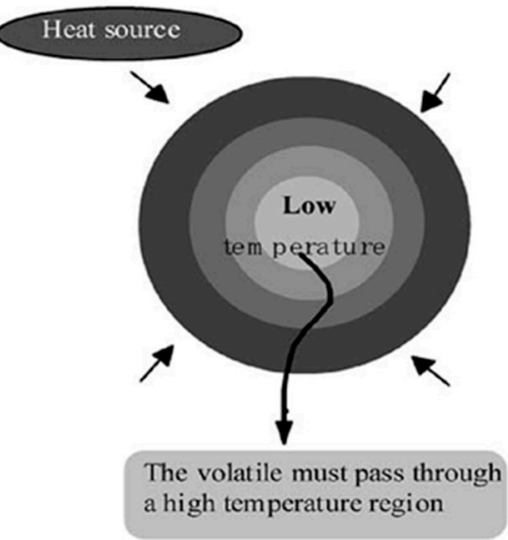

Conventional Heating
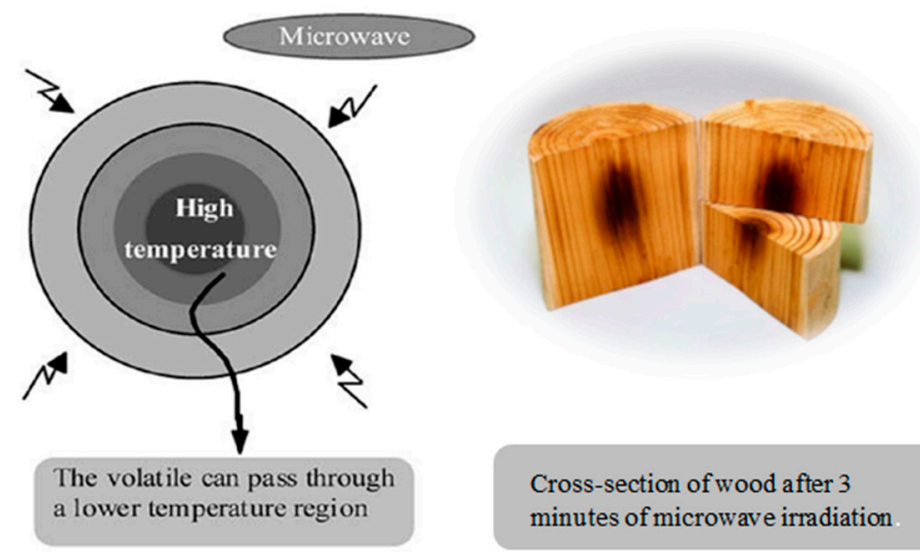

Microwave Heating

Figure 3. Heat transfer in the conventional and microwave heating of wood [70]. (Reproduced with permission from Elsevier).

A sewage sludge pyrolysis under conventional and microwave was carried out to evaluate the feasibility of producing syngas [71]. The total concentration of syngas was higher under microwave heating with values up to $85 \mathrm{vol} \%$ while only $74 \mathrm{vol} \%$ was for conventional heating. However, the calorific value of the gaseous products also increased from $17-25 \mathrm{MJ} / \mathrm{kg}$ in microwave pyrolysis compared to $17-20 \mathrm{MJ} / \mathrm{kg}$ in conventional pyrolysis as a result of the high hydrocarbon concentration in the gas from conventional pyrolysis. Mamaeva et al. [72] pyrolyzed pine sawdust using microwave heating to produce phenolic rich bio-oil. They showed that the maximum content of the phenolic compounds reached $61.19 \%$ (area) at $300{ }^{\circ} \mathrm{C}$. On the other hand, another research study was carried out by Chen et al. [73] where pine wood sawdust was pyrolyzed at $470{ }^{\circ} \mathrm{C}$. They found that the yield of liquid products depended on the type of additive. For instance, the relatively high yield of liquid product resulted from the sample mixed with $\mathrm{H}_{3} \mathrm{PO}_{4}$. This might be related to the transfer of a considerable part of the added $\mathrm{H}_{3} \mathrm{PO}_{4}$ to the liquid because the boiling point of $\mathrm{H}_{3} \mathrm{PO}_{4}$ is slightly higher than $200{ }^{\circ} \mathrm{C}$. The main components of the gaseous products were $\mathrm{CO}, \mathrm{CH}_{4}, \mathrm{CO}_{2}$ and $\mathrm{H}_{2}$. Meanwhile, performing the analysis of the liquid products using a gas chromatograph with a thermal conductivity detector (TCD) showed that there were six organic compounds in the liquid fraction, which were acetol, 2-furanmethanol, furfural, guaiacol, 4-methyl-guaiacol, and levoglucosan. Comparing with the pyrolysis of wood using conventional heating in other studies, a higher distribution of organics was found. Microwave heating may have increased the secondary reaction of levoglucosan produced as gas due to the higher actual temperature of the liquid products governed by dielectric heating. These outcomes confirm that the internal heating mechanism leads to rapid heating, which is more effective than traditional electric heating systems [74]. The bio-oil gained from strong microwave-assisted waste pyrolysis can be further utilized as alternatives or mixtures for petroleum and diesel with better characteristics of high $\mathrm{H}$ content, low $\mathrm{C}$ content, rich monoaromatic compounds, etc. $[66,75,76]$.

\subsection{Effect of Temperature Rate}

In general, microwave heating is expressed in terms of the microwave power output that can be set on the microwave reactor. Normally the temperature in the reactor during the heating treatment is measured using thermocouples. To date, many experimental researches have been implemented to investigate the temperature effect on the pyrolysis of biomass [77,78]. Inguanzo et al. [79] documented that the increase in the pyrolysis temperature of sewage sludge led to a decrease in the solid fraction. However, an increase in the pyrolysis temperature caused an increase the gas fraction productivity meanwhile the liquid products remained almost constant. This can be associated to the mechanism 
of the pyrolysis process, whereby higher temperature promotes the secondary cracking reactions and gives a higher gas yield. It was reported that pyrolysis of pomegranate seeds at temperatures between 400 to $800^{\circ} \mathrm{C}$ resulted in a significant amount of the produced liquid at the temperature of $500{ }^{\circ} \mathrm{C}$ [80]. However, the pyrolysis temperature did not affect the compositions of bio-oil. Interestingly, the amount of the produced gas, especially $\mathrm{CH}_{4}$ and $\mathrm{CO}$, increased when the pyrolysis temperature was increased. A similar trend also was reported when grape bagasse was pyrolyzed at temperatures of $350{ }^{\circ} \mathrm{C}$ to $600{ }^{\circ} \mathrm{C}$ [81]. As the temperature elevated from $350{ }^{\circ} \mathrm{C}$ to $600^{\circ} \mathrm{C}$ at a heating rate of $10^{\circ} \mathrm{C} / \mathrm{min}$, the maximum gas yields were obtained at a value of $39.4 \%$. Furthermore, at a higher temperature up to $900{ }^{\circ} \mathrm{C}$, pore volumes and surface area of bio-char gained from fast pyrolysis of maize stalk chars were significantly enhanced and reached the maximum value at $0.038 \mathrm{~cm}^{3} / \mathrm{g}, 0.029 \mathrm{~cm}^{3} / \mathrm{g}$ and $81.63 \mathrm{~m}^{2} / \mathrm{g}$ for the micropore, mesopore and surface area, respectively [82]. Nonetheless, at a temperature over $900{ }^{\circ} \mathrm{C}$, the pore volume and surface area slightly decreased which was caused by predomination of structural ordering, widening pores and coalescence of neighboring pores. This might also result from the softening; melting, fusing and carbonization caused pores in the bio-chars to be partially blocked. Therefore, this would inhibit the adsorption of gas to the pores and lead to a lower surface area.

\subsection{Effect of Microwave Absorber Addition and Concentration}

Biomass is regularly a low microwave absorber. However, adding the microwave absorbing substances enhances the microwave absorption capacity of treated materials. Many research studies have been conducted. They examined the process of microwave-assisted pyrolysis of biomass without microwave absorbers, and with additives of inorganic substances as absorbers. It was found that utilizing the microwave absorbers can lead to enhancement of the pyrolysis reaction temperature at relatively low microwave power. The microwave absorbers can increase the temperature of the reaction by indirectly heating the surrounding particles of biomass, which finally affect the yield and quality of the product. By the same method, some of studies showed that the microwave absorbers and some catalysts the to the biomass can adjust the distribution of products, improve the energy efficiency of the process or enhance the content of specific bio-oil, bio-char, and gas components under various treatment conditions [83-89]. For instance, the effectiveness of microwave absorber addition and concentration for empty fruit bunch pyrolysis was studied by Omar et al. [90]. The samples were added with $5 \%$ char obtained from the previous pyrolysis. A higher maximum temperature was obtained at $590{ }^{\circ} \mathrm{C}$ compared to that without the absorber of only $177^{\circ} \mathrm{C}$. Increasing the char to $10 \%$ and $15 \%$ did not seem able to elevate the operating temperature. However, the increase in the char concentration enhanced the yield of hydrogen gas while at the same time reducing the yield of $\mathrm{CO}$ and lowering the heating value (LHV). The microwave absorber effect on the microwave pyrolysis of oil palm biomass was investigated by adding oil palm shell char that resulted from traditional pyrolysis [91]. The absorber size was in the range of 100 to $300 \mu \mathrm{m}$. The addition of the microwave absorber at a ratio of 1:0.25 biomass to microwave absorber gives a maximum yield of bio-char at the value of $\sim 70 \%$. This suggested that biomass could not be heated sufficiently when an only small amount of microwave absorber was added to the biomass. Conversely, bio-oil and gas products were produced at a highest ratio of 1:0.5 biomass to microwave absorber at values of $\sim 25$ and $30 \%$, respectively. At this ratio, the attainable maximum operating temperature was at $273^{\circ} \mathrm{C}$.

The combination of char with sewage sludge pyrolyzed under microwave heating improved the syngas production up to $66 \%$ compared to that mixed with graphite produced a lower improvement of $62 \%$ [92]. These values were much higher than those produced by traditional pyrolysis. The heating values of the gases from microwave pyrolysis ranging from 7 to $9.5 \mathrm{MJ} / \mathrm{m}^{3}$ were lower than that obtained from conventional pyrolysis $\left(\sim 14 \mathrm{MJ} / \mathrm{m}^{3}\right)$.

Five metal oxides including, $\mathrm{Al}_{2} \mathrm{O}_{3}, \mathrm{CaO}, \mathrm{Fe}_{2} \mathrm{O}_{3}, \mathrm{TiO}_{2}$ and $\mathrm{ZnO}$ were added into demineralized sewage sludge to be heated under microwave pyrolysis [93]. The addition of $\mathrm{Fe}_{2} \mathrm{O}_{3}$ and $\mathrm{ZnO}$ found was found to favor the formation of solid residue while on the other side it was reduced by adding $\mathrm{Al}_{2} \mathrm{O}_{3}, \mathrm{CaO}$ and $\mathrm{TiO}_{2}$. Hence, it can be assumed that the existence of $\mathrm{Al}_{2} \mathrm{O}_{3}, \mathrm{CaO}$ and $\mathrm{TiO}_{2}$ encouraged 
the degradation of organics matters, causing only small amount of residue to be obtained. Furthermore, the addition of $\mathrm{CaO}$ may support the initial hemicellulose decomposition and further lignin degradation when it enhanced the sludge conversion temperatures below $177^{\circ} \mathrm{C}$ and above $487^{\circ} \mathrm{C}$. At temperatures above $237^{\circ} \mathrm{C}, \mathrm{Fe}_{2} \mathrm{O}_{3}$ restrained the decomposition of cellulose and lignin since it was observed that $\mathrm{Fe}_{2} \mathrm{O}_{3}$ only enhanced the conversion of sludge at low temperatures.

\subsection{Effect of Initial Moisture Content}

Biomass wastes typically have a low ability for microwave absorption. However, the existence of relatively high moisture and inorganic substances may enhance the end product. It was reported that products yields (i.e., bio-oil, bio-gas, and bio-char) gained from microwave-assisted pyrolysis strongly depend on the initial moisture content of the involved feedstock [22]. Three different levels of the initial moisture content $(4,40$ and $75 \%$ ) were applied during the pyrolysis of oily sludge in a microwave environment [28]. The highest volume reduction was achieved in samples with $75 \%$ moisture content, samples whereby only a small amount of solid product was left after the pyrolysis as a result of the increase in temperature evolution in biomass samples for the samples of high moisture content. Moreover, it was observed that the amount of liquid products was directly proportional to the moisture content of each sample. The influence of the initial moisture content on the yield of liquids from the pyrolysis of sawdust was studied in a stainless-steel tube $(95 \mathrm{~mm}$ height $\times 17 \mathrm{~mm}$ inner diameter) [94]. The yields of liquid products increased with the increase in the initial moisture content of the sample. The presence of water in the biomass was found to affect the physical properties and quality of the resultant liquid products. In another research utilizing the same reactor, traditional pyrolysis of spruce wood, hazelnut shells and wheat straw was carried out. The objective was to study the effects of the initial moisture content on the oily products yield and their higher heating values [35]. The drier feedstock was found to encourage the production of high viscosity oil, especially at the higher reaction temperature. The results reported that for higher initial moisture content, the maximum liquid yield on a dry feed basis occurred at lower pyrolysis temperatures of between $416^{\circ} \mathrm{C}$ and $430{ }^{\circ} \mathrm{C}$.

\subsection{Effect of Initial Sweep Gas Flow Rate/Residence Time}

The residence time of a volatile phase is variable depending on the flow rate of the carrier gas, such as nitrogen and helium $[95,96]$. It is used to remove the volatiles from the pyrolysis environment. Minimum secondary reactions such as thermal cracking, repolymerization and re-condensation are very important to obtain maximum liquid yield. The higher gas flow rate will shorten the residence time in the reactor [97]. Thus, their chance to be involved in char forming via secondary decomposition of higher molecular-weight products can be reduced [98]. Various sweep gas flow rates of Nitrogen (200, 400 and $600 \mathrm{~mL} / \mathrm{min}$ ) were applied to pyrolyze Oily sludge under microwave heating to identify the optimum feeding rate and explore the effect of inert gas on the operating temperature condition and product distribution [28]. The temperature profile of the flow rates of 400 and $600 \mathrm{~mL} / \mathrm{min}$ took approximately $10 \mathrm{~min}$ or purpose drying at a temperature around $100{ }^{\circ} \mathrm{C}$ before the temperature increased to around $300^{\circ} \mathrm{C}$ at the 20th min until the end of the process. On the contrary, applying a flow rate of $200 \mathrm{~mL} / \mathrm{min}$ resulted in a slightly higher temperature of $321{ }^{\circ} \mathrm{C}$ that was achieved after $20 \mathrm{~min}$. Therefore, Mokhtar and his co-workers [28] concluded that the nitrogen flow rate of $200 \mathrm{~mL} / \mathrm{min}$ was the optimum feeding rate for microwave-assisted pyrolysis of oily sludge. Fast pyrolysis of sugarcane bagasse was achieved by Parihar et al. [98]. The oil and char yields decreased from $22 \%$ to $19 \%$ and $27 \%$ to $21 \%$, respectively, as the $\mathrm{N}_{2}$ flow rate increased (from 50 to $200 \mathrm{~cm}^{3} \mathrm{~min}^{-1}$ ) while the gas yield increased linearly from $14 \%$ to $23 \%$. The bio-oil obtained from this experiment contains only $0.09 \mathrm{wt} \%$ sulfur, so very low emissions of SOx are expected since the ash content also is very low $(0.02 \mathrm{wt} \%)$. The energy content of the bio-oil ( $37 \mathrm{MJ} \mathrm{kg}^{-1}$ ) is approximately equal to coal (32-37 $\mathrm{MJ} \mathrm{kg}^{-1}$ ) and lower compared to petroleum fuels such as that used in a gas turbine (about $42 \mathrm{MJ} \mathrm{kg}^{-1}$ ). The influence of residence time on sawdust and rice straw pyrolysis was studied by Chen et al. [99]. The residence time required for the optimum pyrolysis was noticeably longer compared to that reported in the 
literature. This could be due to the low average temperature and low reactivity of the biomass fuel. A significant increment of gas yield was observed in the pyrolysis of sawdust and rice straw at a 2.0 and $3.0 \mathrm{~s}$ residence time. Mastral et al. [100] reported that the residence time gives an apparent effect on the product distribution and gas composition especially when the temperature increased from temperatures of $645^{\circ} \mathrm{C}$ to $780{ }^{\circ} \mathrm{C}$ during the pyrolysis of high-density poly-ethylene (HDPE). It could be noticed that the yield of the gas production increased from $11.4 \%$ at $1 \mathrm{~s}$ to $31.5 \%$ at $1.5 \mathrm{~s}$ due to the secondary decomposition reaction. As the temperature rose to up to $780^{\circ} \mathrm{C}$ at $1.3 \mathrm{~s}$, a higher gas yield was obtained at a value of $86.4 \%$ while the rest were oil and waxes.

\section{Conclusions}

Based on the investigation and analysis covered in the earlier sections, the following conclusions and recommendations can be drawn and put forward. Microwave-assisted pyrolysis is basically a novel method for the in-situ processing of biomass waste that can be efficiently done using microwave heating. This issue makes microwave heating a viable route for energy recovery from biomass wastes and for recycling these wastes into useful products. The oils developed using this technique give fewer hazardous compounds and produce more chemicals that are of industry interest, than those attained under conventional pyrolysis. The fact that the gas fraction produces higher yields of hydrogen or syngas is equally beneficial and advantageous. Microwave-assisted pyrolysis, in turn, represents a great chance to remove waste from conventional eco-damaging disposal methods such as landfill and incineration, and it also poses a viable means of extracting commercially valuable products from waste. However, there are still concerns about parameters and the operating conditions that govern this process, which might further need to be optimized. The optimization of the process will allow appropriate process parameters to be defined which will be beneficial in the scale-up of the microwave-assisted pyrolysis process. Base cost analysis is valuable when discovering a new technology. Moreover, the completion of an overall mass-energy balance and economic analysis will assist the commercialization of the microwave-assisted pyrolysis.

Author Contributions: Conceptualization, S.E. and R.O.; methodology, S.E., S.M.M.K. and D.R.A.B.; investigation, S.E.; resources, S.E.; data curation, S.E.; writing-original draft preparation, S.E. and S.A.; writing-review and editing, S.E. and S.L.Z. All authors have read and agreed to the published version of the manuscript.

Funding: This research was funded by Research Management Center of University Putra Malaysia.

Acknowledgments: The authors Thank Research Management Center of University Putra Malaysia for financial support.

Conflicts of Interest: The authors declare no conflict of interest. The funders had no role in the design of the study; in the collection, analyses, or interpretation of data; in the writing of the manuscript, or in the decision to publish the results.

\section{References}

1. Zadeh, Z.E.; Abdulkhani, A.O.; Saha, B. Recent Insights into lignocellulosic biomass pyrolysis: A critical review on pretreatment, characterization, and products upgrading. Processes 2020, 8, 799. [CrossRef]

2. Ethaib, S.; Omar, R.; Kamal, S.M.; Biak, D.A. Microwave-assisted pretreatment of lignocellulosic biomass: A review. J. Eng. Sci. Technol. 2015, 2, 97-109.

3. Ethaib, S. Solid waste situation in Thi-Qar governorate. In IOP Conference Series: Material Science Engineering; IOP Publishing: AlKufa, Iraq, 2019; Volume 584, p. 012023.

4. Ethaib, S.; Omar, R.; Mustapa Kamal, S.M.; Awang Biak, D.R. Comparison of sodium hydroxide and sodium bicarbonate pretreatment methods for characteristic and enzymatic hydrolysis of sago palm bark. Energy Sources Part A Recovery Util. Environ. Eff. 2020, 1-11. [CrossRef]

5. Erabee, I.K.; Ethaib, S. Performane of Activated Carbon Adsorption in Removing of Organic Pollutants from River Water. Int. J. Eng. Technol. 2018, 7, 356-358. [CrossRef]

6. Jung, W.; Savithri, D.; Sharma-Shivappa, R.; Kolar, P. Changes in lignin chemistry of switchgrass due to delignification by sodium hydroxide pretreatment. Energies 2018, 11, 376. [CrossRef] 
7. Gupta, R.; Yadav, G.; Kumar, G.; Yadav, A.; Saini, J.K.; Kuhad, R.C. Second generation bioethanol production: The state of art. In Sustainable Approaches for Biofuels Production; Technologies Springer: Cham, Switzerland, 2019; pp. 121-146.

8. Maj, G.; Najda, A.; Klimek, K.; Balant, S. Estimation of Energy and Emissions Properties of Waste from Various Species of Mint in the Herbal Products Industry. Energies 2020, 13, 55. [CrossRef]

9. Psaltis, P.; Komilis, D. Environmental and economic assessment of the use of biodrying before thermal treatment of municipal solid waste. Waste Manag. 2019, 83, 95-103. [CrossRef]

10. Kar, T.; Keles, S. Environmental impacts of biomass combustion for heating and electricity generation. J. Eng. Res. Appl. Sci. 2016, 5, 458-465.

11. Andrade, L.A.; Batista, F.R.X.; Lira, T.S.; Barrozo, M.A.S.; Vieira, L.G.M. Characterization and product formation during the catalytic and non-catalytic pyrolysis of the green microalgae Chlamydomonas reinhardtii. Renew. Energy 2018, 119, 731-740. [CrossRef]

12. Wu, C.; Budarin, V.L.; Gronnow, M.J.; De Bruyn, M.; Onwudili, J.A.; Clark, J.H.; Williams, P.T. Conventional and microwave-assisted pyrolysis of biomass under different heating rates. J. Anal. Appl. Pyrolysis 2014, 107, 276-283. [CrossRef]

13. Ethaib, S.; Omar, R.; Mazlina, M.; Radiah, A.; Syafiie, S.; Harun, M.Y. Effect of microwave-assisted acid or alkali pretreatment on sugar release from Dragon fruit foliage. Int. Food Res. J. 2016, 23, S149-S154.

14. Ethaib, S.; Omar, R.; Mazlina, M.K.S.; Radiah, A.B.D.; Syafiie, S. Microwave-assisted dilute acid pretreatment and enzymatic hydrolysis of sago palm bark. BioResources 2016, 11, 5687-5702. [CrossRef]

15. Li, X.; Li, K.; Geng, C.; El Mashad, H.; Li, H.; Yin, W. An economic analysis of rice straw microwave pyrolysis for hydrogen-rich fuel gas. RSC Adv. 2017, 7, 53396-53400. [CrossRef]

16. Rahimi, M.A.; Omar, R.; Ethaib, S.; Mazlina, M.S.; Biak, D.A.; Aisyah, R.N. Microwave-assisted extraction of lipid from fish waste. In IOP Conference Series: Materials Science and Engineering; IOP Publishing: Sarawak, Malaysia, 2017; Volume 206, p. 012096.

17. Ethaib, S.; Omar, R.; Mazlina, M.K.S.; Radiah, A.B.D.; Syafiie, S. Development of a hybrid PSO-ANN model for estimating glucose and xylose yields for microwave-assisted pretreatment and the enzymatic hydrolysis of lignocellulosic biomass. Neural Comput. Appl. 2018, 30, 1111-1121. [CrossRef]

18. Fernández Díez, Y.; Arenillas de la Puente, A.; Menéndez Díaz, J.Á. Microwave heating applied to pyrolysis. In Advances in Induction and Microwave Heating of Mineral and Organic Materials; InTec: London, UK, 2011.

19. Ravikumar, C.; Kumar, P.S.; Subhashni, S.K.; Tejaswini, P.V.; Varshini, V. Microwave assisted fast pyrolysis of corn cob, corn stover, saw dust and rice straw: Experimental investigation on bio-oil yield and high heating values. Sustain. Mater. Technol. 2017, 11, 19-27. [CrossRef]

20. Jones, D.A.; Lelyveld, T.P.; Mavrofidis, S.D.; Kingman, S.W.; Miles, N.J. Microwave heating applications in environmental engineering - a review. Resour. Conserv. Recycl. 2002, 34, 75-90. [CrossRef]

21. Lam, S.S.; Russell, A.D.; Lee, C.L.; Chase, H.A. Microwave-heated pyrolysis of waste automotive engine oil: Influence of operation parameters on the yield, composition, and fuel properties of pyrolysis oil. Fuel 2012, 92, 327-339. [CrossRef]

22. Huang, Y.F.; Shih, C.H.; Chiueh, P.T.; Lo, S.L. Microwave co-pyrolysis of sewage sludge and rice straw. Energy 2015, 87, 638-644. [CrossRef]

23. Shang, H.; Lu, R.R.; Shang, L.; Zhang, W.H. Effect of additives on the microwave-assisted pyrolysis of sawdust. Fuel Process. Technol. 2015, 131, 167-174. [CrossRef]

24. Beneroso, D.; Bermúdez, J.M.; Arenillas, A.; Menéndez, J.A. Influence of the microwave absorbent and moisture content on the microwave pyrolysis of an organic municipal solid waste. J. Anal. Appl. Pyrolysis 2014, 105, 234-240. [CrossRef]

25. Kong, S.H.; Lam, S.S.; Yek, P.N.Y.; Liew, R.K.; Ma, N.L.; Osman, M.S.; Wong, C.C. Self-purging microwave pyrolysis: An innovative approach to convert oil palm shell into carbon-rich biochar for methylene blue adsorption. J. Chem. Technol. Biotechnol. 2019, 94, 1397-1405. [CrossRef]

26. Luo, H.; Bao, L.; Kong, L.; Sun, Y. Low temperature microwave-assisted pyrolysis of wood sawdust for phenolic rich compounds: Kinetics and dielectric properties analysis. Bioresour. Technol. 2017, 238, 109-115. [CrossRef] [PubMed]

27. Zhang, Z.; Matharu, A.S. Thermochemical Valorization of Paper Deinking Residue through Microwave-Assisted Pyrolysis. In Waste Biorefinery; Elsevier: Amsterdam, The Netherlands, 2018; pp. 671-692. 
28. Rosi, L.; Bartoli, M.; Frediani, M. Microwave assisted pyrolysis of halogenated plastics recovered from waste computers. Waste Manag. 2018, 73, 511-522. [CrossRef]

29. Mokhtar, N.M.; Ethaib, S.; Omar, R. Effects of microwave absorbers on the products of microwave pyrolysis of oily sludge. J. Eng. Sci. Technol. 2018, 13, 3313-3330.

30. Zhou, J.; Liu, S.; Zhou, N.; Fan, L.; Zhang, Y.; Peng, P.; Chen, P. Development and application of a continuous fast microwave pyrolysis system for sewage sludge utilization. Bioresour. Technol. 2018, 256, 295-301. [CrossRef] [PubMed]

31. Fan, J.; Shuttleworth, P.S.; Gronnow, M.; Breeden, S.W.; Clark, J.H.; Macquarrie, D.J.; Budarin, V.L. Influence of density on microwave pyrolysis of cellulose. ACS Sustain. Chem. Eng. 2018, 6, 2916-2920. [CrossRef]

32. Parvez, A.M.; Wu, T.; Afzal, M.T.; Mareta, S.; He, T.; Zhai, M. Conventional and microwave-assisted pyrolysis of gumwood: A comparison study using thermodynamic evaluation and hydrogen production. Fuel Process. Technol. 2019, 184, 1-11. [CrossRef]

33. Wang, Y.; Zeng, Z.; Tian, X.; Dai, L.; Jiang, L.; Zhang, S.; Ruan, R. Production of bio-oil from agricultural waste by using a continuous fast microwave pyrolysis system. Bioresour. Technol. 2018, 269, 162-168. [CrossRef]

34. Ethaib, S.; Omar, R.; Siti Mazlina, M.K.; Dayang Radiah, A.B. Evaluation of the interactive effect pretreatment parameters via three types of microwave-assisted pretreatment and enzymatic hydrolysis on sugar yield. Processes 2020, 8, 787. [CrossRef]

35. Saadi, W.; Rodríguez-Sánchez, S.; Ruiz, B.; Souissi-Najar, S.; Ouederni, A.; Fuente, E. Pyrolysis technologies for pomegranate (Punica granatum L.) peel wastes. Prospects in the bioenergy sector. Renew. Energy 2019, 136, 373-382. [CrossRef]

36. Demirbas, A. Partial hydrogenation effect of moisture contents on the combustion oils from biomass pyrolysis. Energy Sources Part A Recovery Util. Environ. Eff. 2008, 30, 508-515. [CrossRef]

37. Staš, M.; Chudoba, J.; Kubička, D.; Blažek, J.; Pospíšil, M. Petroleomic characterization of pyrolysis bio-oils: A review. Energy Fuels 2017, 31, 10283-10299. [CrossRef]

38. Vitasari, C.R.; Meindersma, G.W.; De Haan, A.B. Water extraction of pyrolysis oil: The first step for the recovery of renewable chemicals. Bioresour. Technol. 2011, 102, 7204-7210. [CrossRef] [PubMed]

39. Kappler, G.; de Souza, D.M.; Moraes, C.A.M.; Modolo, R.C.E.; Brehm, F.A.; Wander, P.R.; da Cruz Tarelho, L.A. Conversion of Lignocellulosic Biomass Through Pyrolysis to Promote a Sustainable Value Chain for brazilian agribusiness. In Lignocellulosic Biorefining Technologies; John Wiley \& Sons: Hoboken, NJ, USA, 2020; pp. 265-283.

40. Foong, S.Y.; Liew, R.K.; Yang, Y.; Cheng, Y.W.; Yek, P.N.Y.; Mahari, W.A.W.; Aghbashlo, M. Valorization of biomass waste to engineered activated biochar by microwave pyrolysis: Progress, challenges, and future directions. Chem. Eng. J. 2020, 389, 124401. [CrossRef]

41. Yaashikaa, P.R.; Kumar, P.S.; Varjani, S.J.; Saravanan, A. Advances in production and application of biochar from lignocellulosic feedstocks for remediation of environmental pollutants. Bioresour. Technol. 2019, 292, 122030. [CrossRef]

42. Bridgwater, A.V. Review of fast pyrolysis of biomass and product upgrading. Biomass Bioenergy 2012, 38, 68-94. [CrossRef]

43. Khole, P.R.; Shukla, S. Bio-oil production through biomass pyrolysis and upgrading research. Int. J. Agric. Eng. 2018, 11, 257-263. [CrossRef]

44. Qureshi, K.M.; Lup, A.N.K.; Khan, S.; Abnisa, F.; Daud, W.M.A.W. A technical review on semi-continuous and continuous pyrolysis process of biomass to bio-oil. J. Anal. Appl. Pyrolysis 2018, 131, 52-75. [CrossRef]

45. Zhang, Y.M.; Zhu, X.F.; Zhang, L.Q.; Zhu, X.F. Preparation and characterization of microemulsion fuels from diesel and model compound of walnut shell pyrolysis oil. Fuel 2019, 243, 478-484. [CrossRef]

46. Yan, R.; Yang, H.; Chin, T.; Liang, D.T.; Chen, H.; Zheng, C. Influence of temperature on the distribution of gaseous products from pyrolyzing palm oil wastes. Combust. Flame 2005, 142, 24-32. [CrossRef]

47. Yang, H.; Yan, R.; Chen, H.; Lee, D.H.; Liang, D.T.; Zheng, C. Pyrolysis of palm oil wastes for enhanced production of hydrogen rich gases. Fuel Process. Technol. 2006, 87, 935-942. [CrossRef]

48. Klass, D. Biomass for Renewable Energy, Fuel and Chemicals; Academic Press: London, UK, 1998.

49. Thormann, L.; de Oro, P.P. Fuels from Pyrolysis. In Biokerosene; Springer: Berlin/Heidelberg, Germany, 2018; pp. 575-605.

50. Kappe, C.O.; Stadler, A.; Dallinger, D. Microwaves in Organic and Medicinal Chemistry; John Wiley \& Sons: Hoboken, NJ, USA, 2012. 
51. Nascimento, U.M.; Azevedo, E.B. Microwaves and their coupling to advanced oxidation processes: Enhanced performance in pollutants degradation. J. Environ. Sci. Health Part A 2013, 48, 1056-1072. [CrossRef] [PubMed]

52. Ethaib, S.; Omar, R.; Mazlina, M.S.; Radiah, A.D.; Zuwaini, M. Evaluation solvent level effect on sugar yield during microwave-assisted pretreatment. In IOP Conference Series: Materials Science and Engineering; IOP Publishing: Karbala, Iraq, 2020; Volume 871, p. 012034.

53. Quitain, A.T.; Sasaki, M.; Goto, M. Microwave-based pretreatment for efficient biomass-to-biofuel conversion. In Pretreatment Techniques for Biofuels and Biorefineries; Springer: Berlin/Heidelberg, Germany, 2013; pp. 117-130.

54. Ethaib, S.; Omar, R.; Mustapa Kamal, S.M.; Awang Biak, D.R.; Syam, S.; Harun, M.Y. Microwave-assisted pretreatment of sago palm bark. J. Wood Chem. Technol. 2017, 37, 26-42. [CrossRef]

55. Anwar, J.; Shafique, U.; Rehman, R.; Salman, M.; Dar, A.; Anzano, J.M.; Ashraf, S. Microwave chemistry: Effect of ions on dielectric heating in microwave ovens. Arab. J. Chem. 2015, 8, 100-104. [CrossRef]

56. Banik, S.; Bandyopadhyay, S.; Ganguly, S. Bioeffects of microwave-A brief review. Bioresour. Technol. 2003, 87, 155-159. [CrossRef]

57. Hu, Z.; Wen, Z. Enhancing enzymatic digestibility of switchgrass by microwave-assisted alkali pretreatment. Biochem. Eng. J. 2008, 38, 369-378. [CrossRef]

58. Triggle, D.J.; Taylor, J.B. Comprehensive Medicinal Chemistry II; Elsevier: Amsterdam, The Netherlands, 2006; Volume 8.

59. Horikoshi, S.; Schiffmann, R.F.; Fukushima, J.; Serpone, N. Materials Processing by Microwave Heating. In Microwave Chemical and Materials Processing; Springer: Singapore, 2018; pp. 321-381.

60. Kappe, C.O.; Dallinger, D.; Murphree, S.S. Practical Microwave Synthesis for Organic Chemists; John Wiley \& Sons: Hoboken, NJ, USA, 2008.

61. Sun, J.; Wang, W.; Yue, Q. Review on microwave-matter interaction fundamentals and efficient microwave-associated heating strategies. Materials 2016, 9, 231. [CrossRef] [PubMed]

62. Zhang, Y.; Cui, Y.; Liu, S.; Fan, L.; Zhou, N.; Peng, P.; Liu, Y. Fast microwave-assisted pyrolysis of wastes for biofuels production-A review. Bioresour. Technol. 2020, 297, 122480. [CrossRef]

63. Lo, S.L.; Huang, Y.F.; Chiueh, P.T.; Kuan, W.H. Microwave pyrolysis of lignocellulosic biomass. Energy Procedia 2017, 105, 41-46. [CrossRef]

64. Lam, S.S.; Liew, R.K.; Jusoh, A.; Chong, C.T.; Ani, F.N.; Chase, H.A. Progress in waste oil to sustainable energy, with emphasis on pyrolysis techniques. Renew. Sustain. Energy Rev. 2016, 53, 741-753. [CrossRef]

65. Menéndez, J.A.; Inguanzo, M.; Pis, J.J. Microwave-induced pyrolysis of sewage sludge. Water Res. 2002, 36, 3261-3264. [CrossRef]

66. Dominguez, A.; Fernandez, Y.; Fidalgo, B.; Pis, J.J.; Menendez, J.A. Bio-syngas production with low concentrations of $\mathrm{CO}_{2}$ and $\mathrm{CH}_{4}$ from microwave-induced pyrolysis of wet and dried sewage sludge. Chemosphere 2008, 70, 397-403. [CrossRef]

67. Dominguez, A.; Menendez, J.A.; Inguanzo, M.; Bernad, P.L.; Pis, J.J. Gas chromatographic-mass spectrometric study of the oil fractions produced by microwave-assisted pyrolysis of different sewage sludge. J. Chromatogr. A 2003, 1012, 193-206. [CrossRef]

68. Dominguez, A.; Menendez, J.A.; Inguanzo, M.; Pis, J.J. Investigations into the characteristics of oils produced from microwave pyrolysis of sewage sludge. Fuel Process. Technol. 2005, 86, 1007-1020. [CrossRef]

69. Nhuchhen, D.R.; Afzal, M.T.; Dreise, T.; Salema, A.A. Characteristics of biochar and bio-oil produced from wood pellets pyrolysis using a bench scale fixed bed, microwave reactor. Biomass Bioenergy 2018, 119, $293-303$. [CrossRef]

70. Miura, M.; Kaga, H.; Sakurai, A.; Kakuchi, T.; Takahashi, K. Rapid pyrolysis of wood block by microwave heating. J. Anal. Appl. Pyrolysis 2004, 71, 187-199. [CrossRef]

71. Shi, K.; Yan, J.; Menéndez, J.A.; Luo, X.; Yang, G.; Chen, Y.; Wu, T. Production of $\mathrm{H}_{2}$-rich syngas from lignocellulosic biomass using microwave-assisted pyrolysis coupled with activated carbon enabled reforming. Front. Chem. 2020, 8, 3. [CrossRef]

72. Mamaeva, A.; Tahmasebi, A.; Tian, L.; Yu, J. Microwave-assisted catalyticpyrolysis of lignocellulosic biomass for production of phenolic-rich bio-oil. Bioresour. Technol. 2016, 211, 382-389. [CrossRef]

73. Chen, M.Q.; Wang, J.; Zhang, M.X.; Chen, M.G.; Zhu, X.F.; Min, F.F.; Tan, Z.C. Catalytic effects of eight inorganic additives on pyrolysis of pine wood sawdust by microwave heating. J. Anal. Appl. Pyrolysis 2008, 82, 145-150. [CrossRef] 
74. Gautam, R.; Shyam, S.; Reddy, B.R.; Govindaraju, K.; Vinu, R. Microwave-assisted pyrolysis and analytical fast pyrolysis of macroalgae: Product analysis and effect of heating mechanism. Sustain. Energy Fuel. 2019, 3, 3009-3020. [CrossRef]

75. Zhang, Y.; Chen, P.; Liu, S.; Peng, P.; Min, M.; Cheng, Y.; Anderson, E.; Zhou, N.; Fan, L.; Liu, C.; et al. Effects of feedstock characteristics on microwave-assisted pyrolysis-a review. Bioresour. Technol. 2017, 230, 143-151. [CrossRef] [PubMed]

76. Wang, W.C.; Lee, A.C. The study of producing "drop-in" fuels from agricultural waste through fast pyrolysis and catalytic hydro-processing. Renew. Energy 2019, 133, 1-10. [CrossRef]

77. Zhou, J.; Gao, P.; Dong, C.; Yang, Y. Effect of temperature and mineral matter on the formation of NOx precursors during fast pyrolysis of 2, 5-diketopiperazine. Energies 2018, 11, 629. [CrossRef]

78. Bartoli, M.; Rosi, L.; Giovannelli, A.; Frediani, P.; Frediani, M. Bio-oil from residues of short rotation coppice of poplar using a microwave assisted pyrolysis. J. Anal. Appl. Pyrolysis 2016, 119, 224-232. [CrossRef]

79. Salema, A.A.; Afzal, M.T.; Bennamoun, L. Pyrolysis of corn stalk biomass briquettes in a scaled-up microwave technology. Bioresour. Technol. 2017, 233, 353-362. [CrossRef]

80. Inguanzo, M.; Dominguez, A.; Menendez, J.A. Blanco CG On the pyrolysis of sewage sludge: The influence of pyrolysis conditions on solid, liquid and gas fractions. J. Anal. Appl. Pyrolysis 2002, 63, 209-222. [CrossRef]

81. Uçar, S.; Karagöz, S. The slow pyrolysis of pomegranate seeds: The effect of temperature on the product yields and bio-oil properties. J. Anal. Appl. Pyrolysis 2009, 84, 151-156. [CrossRef]

82. Demiral, I.; Ayan, E.A. Pyrolysis of grape bagasse: Effect of pyrolysis conditions on the product yields and characterization of the liquid product. Bioresour. Technol. 2011, 102, 3946-3951. [CrossRef]

83. Fu, P.; Yi, W.; Bai, X.; Li, Z.; Xiang, J. Effect of temperature on gas composition and char structural features of pyrolyzed agricultural residues. Bioresour. Technol. 2011, 102, 8211-8219. [CrossRef]

84. Mushtaq, F.; Ramli, M.; Farid, N.A. A review on microwave assisted pyrolysis of coal and biomass for fuel production. Renew. Sustain. Energy Rev. 2014, 39, 555-574. [CrossRef]

85. Ren, S.; Lei, H.; Wang, L.; Yadavalli, G.; Liu, Y.; Julson, J. The integrated process of microwave torrefaction and pyrolysis of corn stover for biofuel production. J. Anal. Appl. Pyrolysis 2014, 108, 248-253. [CrossRef]

86. Fernández, Y.; Menéndez, J.A. Influence of feed characteristics on the microwave-assisted pyrolysis used to produce syngas from biomass wastes. J. Anal. Appl. Pyrolysis 2011, 91, 316-322. [CrossRef]

87. Zhao, X.; Song, Z.; Liu, H.; Li, Z.; Li, L.; Ma, C. Microwave pyrolysis of corn stalk bale: A promising method for direct utilization of large-sized biomass and syngas production. J. Anal. Appl. Pyrolysis 2010, 89, 87-94. [CrossRef]

88. Du, Z.; Li, Y.; Wang, X.; Wan, Y.; Chen, Q.; Wang, C.; Ruan, R. Microwave-assisted pyrolysis of microalgae for biofuel production. Bioresour. Technol. 2011, 102, 4890-4896. [CrossRef] [PubMed]

89. Mašek, O.; Budarin, V.; Gronnow, M.; Crombie, K.; Brownsort, P.; Fitzpatrick, E.; Hurst, P. Microwave and slow pyrolysis biochar-Comparison of physical and functional properties. J. Anal. Appl. Pyrolysis 2013, 100, 41-48. [CrossRef]

90. Menéndez, J.A.; Arenillas, A.; Fidalgo, B.; Fernández, Y.; Zubizarreta, L.; Calvo, E.G.; Bermúdez, J.M. Microwave heating processes involving carbon materials. Fuel Process. Technol. 2010, 91, 1-8. [CrossRef]

91. Omar, R.; Idris, A.; Yunus, R.; Khalid, K.; Aida Isma, M.I. Characterization of empty fruit bunch for microwave-assissted pyrolysis. Fuel 2010, 90, 1536-1544. [CrossRef]

92. Salema, A.A.; Ani, F.N. Microwave induced pyrolysis of oil palm biomass. Bioresour. Technol. 2011, 102, 3388-3395. [CrossRef]

93. Dominguez, A.; Menendez, J.A.; Inguanzo, M.; Pis, J.J. Production of bio-fuels by high temperature pyrolysis of sewage sludge using conventional and microwave heating. Bioresour. Technol. 2006, 97, 1185-1193. [CrossRef]

94. Shao, J.; Yan, R.; Chen, H.; Yang, H.; Lee, D.H. Catalytic effect of metal oxides on pyrolysis of sewage sludge. Fuel Process. Technol. 2010, 91, 1113-1118. [CrossRef]

95. Demirbas, A. Relationship between initial moisture content and the liquidyield from pyrolysis of sawdust. Energy Sources 2005, 27, 823-830. [CrossRef]

96. Dhanavath, K.N.; Bankupalli, S.; Sugali, C.S.; Perupogu, V.; Nandury, S.V.; Bhargava, S.; Parthasarathy, R. Optimization of process parameters for slow pyrolysis of neem press seed cake for liquid and char production. J. Environ. Chem. Eng. 2019, 7, 102905. [CrossRef] 
97. Brassard, P.; Godbout, S.; Raghavan, V. Pyrolysis in auger reactors for biochar and bio-oil production: A review. Biosyst. Eng. 2017, 161, 80-92. [CrossRef]

98. Parihar, M.F.; Kamil, M.; Goyal, H.B.; Gupta, A.K.; Bhatnagar, A.K. An experimental study on pyrolysis of biomass. Trans IChemE Part B, Process Saf. Environ. Prot. 2007, 85, 458-465. [CrossRef]

99. Chen, G.; Andries, J.; Spliethoff, H. Catalytic pyrolysis of biomass for hydrogen rich fuel gas production. Energy Convers. Manag. 2003, 44, 2289-2296. [CrossRef]

100. Mastral, F.J.; Esperanza, E.; Garcia, P.; Juste, M. Pyrolysis of high-density polyethylene in a fluidized bed reactor. Influence of the temperature and residence time. J. Anal. Appl. Pyrolysis 2002, 63, 1-15. [CrossRef] 